\title{
Üniversitelerin Sosyal Kültürel ve Ekonomik Fonksiyonlarının Şehirler Üzerindeki Etkileri ${ }^{1}$
}

\author{
The Effects Of Untversities 'Social, Cultural And Economic Functions On Cities
}

Gökhan KÖMÜR *

$\ddot{O} Z$

Modern dünyanın ortaya çıkardığı yeni aktörler ve yeni anlayışlar, ülkelerin ve şehirlerin birçok alanda gelişim göstermesini zorunlu hale getirmektedir. Bu gelişimin bir parçası olarak üniversiteler de şehirlerin ekonomik, kültürel ve sosyal değişiminde son zamanlarda önem arz eden aktörler olarak karşımıza çıkmaktadır. Toplumsal değişimin aktörleri olan üniversiteler, bu değişimin birer lokomotifi durumundadır. Bu çalışmanın amacl; üniversite-şehir ilişkisini inceleyerek, üniversitelerin şehirlere olan sosyal, kültürel ve ekonomik etkilerini ortaya koymaktır. Bu bağlamda Türkiye'nin en genç üniversitelerinden biri olan Bayburt Üniversitesi ve Bayburt İli örnek olarak alınmıştır. Bu çalışmadan çıkacak sonuçlar, Bayburt ilinin geçen süre zarfinda değişimini gösterecek, Bayburt ile ilgilenen araştırmacılara bir kaynak niteliği taşıyacak ve diğer il ve üniversitelere de örnek teşkil edecektir.

ANAHTAR KELIMELER

Kurumsal İmaj, Üniversite Şehir İlişkisi, Algı Araştırması

\begin{abstract}
The new actors and new understandings of the modern world make it necessary for countries and cities to develop in many areas. As a part of this development, universities are also important actors in the economic, cultural and social changes of cities in recent times. Universities, as actors of social change, are the locomotives of this change. The aim of this study is; examining the relationship between university and city, to reveal the social, cultural, and economic effects of universities to cities. In this context, Bayburt University, which is one of the youngest universities in our country, and Bayburt Province was taken as an example. The results of this study will show the change of Bayburt province during the time period; be a source for the researchers interested in Bayburt and serve as a model for other provinces and universities.
\end{abstract}

KEYWORDS

Institution Image, University and City Relations, Perception Research

\begin{tabular}{|c|c|c|}
\hline \multicolumn{2}{|r|}{$\begin{array}{c}\text { Makale Geliş Tarihi / Submission Date } \\
\text { 07.02.2021 }\end{array}$} & $\begin{array}{c}\text { Makale Kabul Tarihi / Date of Acceptance } \\
\text { 09.03.2021 }\end{array}$ \\
\hline Atıf & $\begin{array}{l}\text { Kömür, G. (2021). Üniversitelerin Sos } \\
\text { Üniversitesi Sosyal Bilimler Meslek Yi }\end{array}$ & $\begin{array}{l}\text { k Fonksiyonlarının Şehirler Üzerindeki Etkileri. Selçuk } \\
\text { 1), 101-114. }\end{array}$ \\
\hline
\end{tabular}

\footnotetext{
${ }^{1}$ Bu makale “Üniversitelerin Şehirler Üzerindeki Sosyal Kültürel ve Ekonomik Etkilerine Yönelik Bir Algı Araştırması”” adlı doktora tezinden üretilmiștir.

* Dr. Öğr. Üyesi, Bayburt Üniversitesi Demirözü Meslek Yüksekokulu, gkomur@bayburt.edu.tr, ORCID: 0000-0002-7516-2560
} 


\section{GİRIŞ}

Hızla gelişen teknoloji ve sunmuş olduğu imkânlar günümüzde insan yaşamına sayısız fayda sağlamaktadır. $\mathrm{Bu}$ faydalar dünyada ve Türkiye'de yaşanan rekabet koşulları arasında insanlara birbirleri ile rekabet etmek için de aynı zamanda birer araç oluşturmaktadır. Teknoloji sayesinde bilgiye ulaşmanın çok kolay olduğu, iletişim olanaklarının üstün bir seviyeye ulaştığı insanların artık dünyanın hangi köşesinde olursa olsun her türlü olaydan haberdar olduğu günümüzde evrensel bir değer olan üniversiteler, bulundukları şehre iş, bilgi, eğitim, kültür, sosyal hizmetler ve ekonomik kalkınma konusunda çok önemli imkânlar sunmaktadırlar. Bunların yanında şehir kültürünün oluşmasına ve daha sonra şekillenmesi noktasındaki tüm değerlere etki etmektedirler. Bu bağlamda bakıldığında değişen dünya eğilimlerine ayak uydurmak için değişen ve çeşitlenen beklentiler ve ihtiyaçlar üniversitelere büyük görev atfetmektedir. Üniversiteler ise üzerlerine düşen bu görevleri bulundukları şehre ve o şehrin insanına karşı büyük bir özveri ve sorumluluk ile yerine getirmek için büyük bir çaba sarf etmektedirler. Sunmuş oldukları eğitim, araştırma, proje üretme ve uygulama, sosyal sorumluluk faaliyetleri, topluma hizmet uygulamaları, istihdam oluşturma gibi hizmetleri ile değişen sistemin dinamiklerine cevap vererek üzerlerine almış oldukları sorumluluklarını yerine getirmektedirler.

Üniversiteler ilk önce kurulmuş olduğu şehirlere daha sonra uluslararası boyutta yükseköğretimin öneminin ve değerinin her geçen gün arttı̆̆ noktada üzerine düşen görev ve sorumlulukları yerine getirmek için çalışmaktadırlar. Bazı üniversitelerin bulunduğu jeopolitik konumdan dolayı çevresi ile bağlantısının sınırlı olması, coğrafi şartlardan dolayı tarıma çok elverişli olmaması, sanayi sektörünün yok denecek kadar az olması ve hizmet sektörünün yüksek bir orana sahip olması gibi durumlar özellikle üniversitelerin şehre ve topluma olan etkisini önemli bir hâle getirmiştir.

Bu çalışmanın amacı üniversite şehir ilişkisini inceleyerek üniversitelerin şehirlere olan sosyal, kültürel ve ekonomik etkilerini araştırmaktır. Bu bağlamda Türkiye'nin en genç üniversitelerinden biri olan Bayburt Üniversitesi ve Bayburt ili örnek olarak alınmıştır. Bu çalışma üniversitenin kültürel, sosyal ve ekonomik etkisine yönelik bir araştırma olduğu gibi aynı zamanda halkla ilişkilere yönelik bir araştırmadır. Bayburt Üniversitesi'nin şehre olan etkileri tek yönlü olmayıp karşılıklı bir ilişkinin sonucu olarak ortaya çıkmaktadır.

Çalışmanın birinci bölümünde üniversite şehir ilişkisi ele alınmış ve beş başlık altında incelenmiştir. Çalışmanın ikinci bölümünde özellikle yeni kurulan üniversitelerin kurulmuş oldukları şehir ile olan ilişkilerini ele alan araştırmalara yer verilerek detaylı bir literatür araştırması yapılmıştır. Çalışmanın üçüncü bölümünde ise çalışmanın amacı, önemi, araştırmanın yöntemi ve veri toplama-analiz teknikleri anlatılmıştır.

\section{1. ÜNIVERSITE ŞEHIR İLIŞKISI}

Üniversiteler kuruldukları bölgenin ekonomileri açsından geniş bir perspektifte çok sayıda kişiyi istihdam ettikleri, yerel mal ve hizmetleri satın aldıkları, şehrin kültürel yaşantısının ve çevresinin ortakları oldukları için şehrin önemli kurumlarıdır (Yavuzçehre, 2016: 236). Bu kurumların önemi her geçen gün artmakta ve şehir halkı bu kurumları daha çok sahiplenmektedir.

Şehir ve üniversite arasındaki ilişkilerin geliştirilmesinde şehir ve üniversite yönetiminin, kentin siyasi, sosyal, ekonomik ve kültürel yapısında etkili olan paydaşların şehre yönelik karar alma mekanizmalarında bulunan etkili dinamiklerin önemi büyüktür. Bununla beraber şehirde yaşayan halkın şehir ve üniversite yönetiminden bağımsız bireyler olarak üniversiteye yönelik fikirleri, üniversite şehir ilişkisinde dikkate alınması gereken en önemli hususlardan birisidir (Sankır ve Gürdal, 2014: 92).

\section{1. Üniversitelerin Şehirlere Olan Etkileri}

Üniversitelerin kurulmuş oldukları şehrin ilk başta demografik yapısına, zaman geçtikçe ekonomisine, çevresel yapılanmasına, toplumsal olgunlaşmasına, mesleki gelişimine, spor ve fiziksel aktivite mekânlarına doğrudan ve dolaylı katkıları bulunmaktadır. Üniversitelerin bu faydaları büyük şehirlerde daha az görülürken küçük şehirlerde bu fayda daha çok hissedilmektedir (Yavuzçehre, 2016: 236).

Üniversitelerin kuruldukları bölgelerde o bölge ile sıkı ilişki içine girmenin sağlayacağı faydaları Cox'un (2000) modelini Türkiye'ye göre değiştirip yorumlayarak aktaran Gürkaynak ve Kasımoğlu (2004) bu faydaları şu şekilde sıralamışlardır: i. Beşeri sermayenin iyileştirilmesi, ii. sosyal sermayenin hareketlendirilmesi, iii. fiziksel çevrenin iyileştirilmesi, iv. ekonomik yapının güçlendirilmesi, v. yurttaşlık bilinç ve becerilerinin kazanılması. 
Şekil 1. Üniversitelerin Kuruldukları Şehre Muhtemel Etkileri (Özbay, 2013: 17)

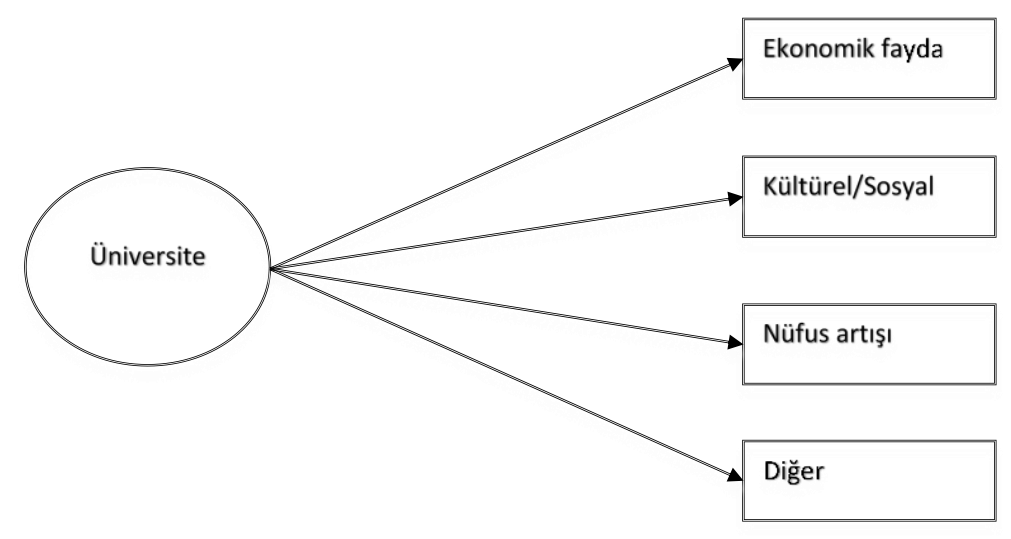

Üniversitelerin şehirlere olan etkileri kurulmuş olduğu şehre, bölgeye üniversitelerin büyüklüğüne göre değişiklik göstermektedir. Bu etkileri demografik, ekonomik, sanayi, çevresel, sosyal ve kültürel etkiler olmak üzere beş başlık altında incelenip ele alınacaktır.

Demografik Etkiler: Üniversitelerin şehirlere kurulmasından sonra en hılı ve belirgin etkileri demografik etkiler olmaktadır. Özellikle üniversite küçük ölçekli bir şehirde kurulduysa bu etki çok daha belirgin şekilde göze çarpmaktadır. Üniversitelerin zamanla büyümesi, üniversite öğrenci ve personel sayısının giderek artması sonucu şehirlerin göç ve nüfus özelliklerindeki değişimleri de beraberinde getirmektedir. Üniversitelerin şehirlere kurulmasından sonraki geçen zaman diliminde nüfus yoğunluğunun öğrenci lehine artışı, toplumsal değişimi, şehrin öğrencileşmesi olarak adlandırılmaktadır (Yavuzçehre, 2016: 236).

Ekonomik Etkiler: Yukarıdaki açıklamalardan hareketle Türkiye'de 1980 ve özellikle de 1992 yılından sonra kurulan üniversiteler, bölgesel kalkınma ve gelişmenin lokomotifi olarak tanımlanmıştır (Yılmaz, 2011: 4). Üniversitelerin temel görevi kişisel gelişim ve insanların entelektüel hayatlarına katkı sağlamak olsa da üniversitelerin ekonomik etki potansiyelleri de bulunmaktadır (Görkemli, 2009: 171). Bir bölgede üniversite kurulması, üniversiteye mal ve hizmet sunan diğer sektörlerin faaliyet alanlarını da genişletir. Üniversitelerin bölge ekonomisine sağladığı bu katkılar üniversite sayısının her geçen gün hızla arttı̆̆ Türkiye'de beklenen temel faydalardır (Atik, 1999: 99).

Mekânsal Etkiler: Üniversitelerin kurulması ile şehirleşme ve şehirlileştirme kavramları kullanılmaya başlanmıştır. Buradan hareketle üniversitelerin kuruldukları bölgeye daha bir şehir havası verdiği vurgulanmak istenmiştir. Üniversiteler şehirlerin gelişmesini bu anlamda sağlarken sosyal ve kültürel olarak da değişim sağlamaktadırlar (Sargın, 2006: 191). Üniversiteler, özellikle az gelişmiş bölgelerde bulunan hantallaşmış, modern hayatın gerekliklerine uyum sağlayamamış yapıların ortadan kalkmasını sağlarken aynı zamanda çağdaş yapıların ortaya çıkmasına da etki ederler. Bunun yanında üniversiteler kuruldukları bölgenin alt kültürleri ile ulusal kültürünü aynı potada eriterek yeni kültür yapılarının oluşmasına da etki ederler (Gültekin ve diğ. 2008: 266).

Özel Sektör ve Sanayiye Etkileri: Üniversiteler kuruldukları şehrin sanayi kuruluşları ile işbirliği yaparak, sahip oldukları bilgi birikimlerini sanayi kesimi ile paylaşarak daha etkili ve verimli olmaları için önemli faydalar sağlarlar (Gültekin ve diğ. 2008: 266). Üniversitelere çeşitli sektörlerde faaliyet gösteren firmaların personeline eğitim vererek onların gelişimine yönelik faaliyetleri ile de firmalara önemli ölçüde destek sağlamaktadırlar (Çalışkan, 2010: 171).

Artan rekabet ortamında teknoloji, girişimcilik, inovasyon gibi konular üniversite ve şehirler için ortak unsurlardır. Bu kavramlar ayrıca sanayi ve üniversitelerin kesişme noktasını oluşturmaktadırlar (Yavuzçehre, 2016: 241).

Sosyal ve Kültürel Yapıya Etkileri: Üniversiteler geçmişten günümüze bakıldığında Türkiye'de, Cumhuriyet tarihinden itibaren değişik süreçler ve değişik şekillerde toplumsal değişimleri ve gelişmeleri etkileyen önemli kurumlar olarak ortaya çıkmaktadır. Geçen bu süre zarfında üniversitelerin ilişki kurduğu şehirlerde kurmuş oldukları doğrudan ilişkilerini ve meydana getirdikleri değişimleri görmek mümkündür. $\mathrm{Bu}$ doğrultudan hareketle özellikle şehir dışından gelen üniversite personelinin ve üniversite öğrencilerinin beraber getirdikleri kültürel değerler ile şehre alışma çabaları şehirde yaşanan değişimin rotasını çizmekte ve hızını ayarlamaktadır (Sağır ve İnci, 2013: 51). 


\section{2. Şehrin İmajı Üzerindeki Etkileri:}

Üniversitelerin fonksiyonlarını eksiksiz bir biçimde gerçekleştirmesi ve tüm toplumun desteğini kazanması etkili bir kurum imajına sahip olması ile mümkün hale gelmektedir (Torun ve diğerleri, 2009: 170). Üniversitelerin sahip olmuş olduğu sorumluluk dâhilinde olumlu bir kurum imajı oluşturması ve bu imaj1 çevresine yansıtması büyük bir önem arz etmektedir. Halka ilişkilerin en önemli ilkelerinden biri de halkta olumlu bir imaj oluşturmaktır (Geçikli, 2008: 21).

\section{LITERATÜR ARAŞTIRMASI}

Son dönemlerde özellikle yeni kurulan üniversitelerin kurulmuş oldukları şehirle olan ilişkilerini ele alan araştırmalara sıklıkla rastlanmaktadır. Bahsedilen bu çalışmalar üniversite şehir ilişkisini ekonomik boyutu ile ele alan çalışmalar, sosyo-ekonomik boyutuyla ele alan çalışmalar, sosyal ve sosyal kültürel boyutuyla ele alan çalışmalar, sosyo mekânsal boyutuyla ele alan çalışmalar ve mekânsal boyutuyla ele alan çalışmalar olmuştur. $\mathrm{Bu}$ çalışmaların sayısı oldukça fazla olduğu için sadece önemli görülenlere bu araştırmada yer verilmiştir

\section{1. Üniversite Şehir İlişkisini Ekonomik Katkılar Açısından Ele Alan Çalışmalar}

Atik (1999)'e göre üniversiteler yaptıkları harcamalar ve sağladıkları istihdam açısından kuruldukları şehirlerin en önemli aktöreleridir. Üniversitelerin yerel ekonomi üzerindeki pozitif etkilerini direkt, dolaylı ve uyarılmış etkiler olarak üç grupta ele alarak incelemiştir.

Erkekoğlu (2000), Cumhuriyet Üniversitesi'nin Sivas'ın ekonomisine gelir ve istihdam katkılarını dolaylı ve direkt katkılar olarak iki başlık altında ele alarak incelenmiş uyarılmış katkılar ise verilerin yetersizliği nedeni ile araştırmaya dâhil edilmemiştir. Elde edilen sonuçlara göre 1998-1999 öğretim yılında Cumhuriyet Üniversitesi 2170 kişiye direkt istidam ve 4,6 trilyon direkt gelir sağlamış ve bu dönemde 4965 kişiye dolaylı istihdam sağlarken 15,4 trilyon dolaylı gelir sağladığı tespit edilmiştir.

Görkemli (2009), Türkiye'nin öğrenci sayısı açısından en büyük üniversitelerinden biri olan ve araştırma tarihi dikkate alındığında şehirdeki tek üniversite olan Selçuk Üniversitesinin Konya'ya ya olan etkilerini direkt, dolaylı ve uyarılmış etkiler olarak üç grupta incelemiştir. Araştırma değerlendirme ve sonuçlarına göre üniversite 2002-2003 öğretim yılında 4205 kişiye direkt istihdam sağlarken 41.069.000 TL gelir sağlamıştır. Aynı dönemde yapılan bütçe harcamaları 13.980.000 dolaylı gelir sağlarken 559 kişiye dolaylı istihdam sağlanmıştır. 2003 yılında öğrenci harcamaları yolu ile 182.964.387 TL gelir sağlanırken yine öğrenci harcamaları yolu ile 7.315 kişiye istihdam sağlanmıştır.

Torun vd. (2009), Kafkas Üniversitesinin şehrin ekonomik gelişimine etkisini, üniversitenin kurumsal imajını ve şehir halkının üniversiteden beklentilerini inceleyerek ele almışlardır. Bu çalışma sonucu üniversitenin Kars halkı tarafından tanınan bir kurum olduğu ve üniversitenin toplumun büyük kesiminde kabul gördüğü anlaşılmıştır. Üniversitenin olumlu bir imaj oluşturabilmek için halk tarafindan kabul görmeye, Kars'ın da kendi olumlu imajına sahip olmasında üniversiteye ihtiyacı olduğu savunulmuştur.

Çalışkan (2010), Uşak Üniversitesi öğrencilerinin yapmış oldukları harcamaların miktarını, bileşenlerini ve şehir ekonomisine etkisini cinsiyet farklılıklarını da dikkate alarak incelemiştir. Araştırmanın sonuçlarına göre öğrencilerin yapmış oldukları harcamaların Uşak için çok önemli bir ekonomik katkı sağladığı tespit edilmiştir.

Akçakanat vd. (2011) yaptıkları çalışmalarında SDÜ öğrencilerinin Isparta'daki yaşam şartları hakkındaki fikirlerini öğrenmek ve Isparta esnafı, halkı ve ev sahipleri ile ilgili algılarını tespit etmeye çalışmışlardır. Araştırma kapsamında 2003-2005-2007 ve 2009 yılları ele alınmış ve yıllar arasındaki memnuniyet seviyeleri arasında meydana gelen farklılıklar tespit edilmeye çalışılmıştır. Araştırma sonucunda öğrencilerin Isparta' daki yaşam standartlarından ve Isparta halkının tutum ve davranışlarından memnun olmadıkları ortaya çıkmıştır.

Torun ve Öztürk (2013), üniversitelerin bölgesel kalkınma farklarını azaltmak, şehirleşme ve demokrasi kültürünün yerleşmesi gibi ikincil bir fonksiyona sahip olduğunu savunmuşlar ve bu konuda yeni kurulan üniversitelerin eskilerinden daha etkili ve verimli olduklarını dile getirmişlerdir. Bu doğrultuda yapılan bu çalışmayı üniversitelerin artan önemi, üniversitelerin bilgi üretme fonksiyonu, üniversitelerin sosyo-kültürel fonksiyonları, yeni kurulan üniversitelerin birincil ve ikincil işlevleri başlıkları altında incelemişlerdir.

Tösten vd. (2013), çalışmalarında Dicle Üniversitesinde okuyan öğrencilerin harcama durumları farklı değişkenler arasında test edilerek öğrencilerin şehir ekonomisine katkıları analiz edilmiştir. 829 üniversite öğrencisine uygulanan anket sonuçlarına göre öğrencilerin birçoğu Dicle Üniversitesini memleketlerine yakın olduğu gerekçesi ile tercih ettiği, öğrencilerinin büyük bir çoğunluğunun Güneydoğu Anadolu bölgesinden geldiği, Diyarbakır ilini mali olarak yaşamak için uygun bulunduğunu ve Dicle Üniversitesini tavsiye ettikleri tespit edilmiştir. 
Demireli ve Taşkın (2013), çalışmalarında Dumlupınar Üniversitesi’nin Kütahya iline olan diğer katkıları ile özellikle ekonomik katkılarını ele almışlardır. Sonuç olarak 2010 yılında bir öğrencinin aylık $495 \mathrm{Tl}$ bir harcama yaptığı tespit edilmiş ve bu harcamanın Kütahya ili ekonomisine ortalama aylık 15 Milyon TL'lik bir katkı sağladığı sonucuna varılmıştır.

Köksal vd. "Üniversitelerin Bulundukları Şehirlere Ekonomik Katkıları Üzerine Bir Literatür Değerlendirmesi” adlı çalışmalarında Üniversitelerin bulundukları bölgenin ekonomisine, sosyo-kültürel yaşamına, idari faaliyetlerine olan dolaylı ya da doğrudan etkilerini çeşitli araştırmalar yaparak bir literatür taramasından geçirerek incelemişlerdir. $\mathrm{Bu}$ araştırma spesifik olarak öğrenci harcamaları üzerine odaklanmıştır. Sonuç olarak üniversitelerin yerel ekonomiye olan katkısının öğrenci harcamalarından daha fazla olduğu tespit edilmiştir.

Aslan ve Sırrım (2019) Üniversite öğrencilerinin yaptıkları harcamalarının şehir ekonomisine faydalarını tespit etmek amacıyla gerçekleştirdikleri çalışmalarında Namık Kemal Üniversitesinin, kuruluşundan 2017 yılına kadar İlçeye 1012 milyar TL'lik ekonomik fayda sağladığı, 1044 akademik personel, 540 idari personel ve 821 diğer personel olmak üzere; toplam 2405 kişiye doğrudan istihdam kaynağı olduğu tespit edilmiştir.

Acar ve Özbekler (2019) üniversite öğrencilerinin ilçe ekonomisine katkılarını araştırdıkları çalışmalarında Sinop İli Ayancık İlçesinde bulunan MYO öğrencilerinin yaptıkları harcamaların ilçe ekonomisine etkilerini incelemişlerdir. Araştırma sonuçlarına göre üniversite öğrencilerinin yaptığı harcamaların ilçe ekonomisinin kalkınmasında ve piyasanın hareketlenmesinde büyük bir paya sahip olduğu ortaya çıkmıştır.

\section{2. Üniversite Şehir İlişskisini Sosyo-Ekonomik ve Kültürel Açıdan Ele Alan Çalışmalar}

Çınar ve Emsen (2001), Atatürk Üniversitesinin 43 y1llık tarihini incelemiş ve üniversitenin mevcut alt yapısı göz önüne alınarak Erzurum'un sosyal ve ekonomik hayatına etkisini tespit etmeye çalışmışlardır. Bu bağlamda Üniversite kuruluş kanundaki amacına uygun olarak ülke ekonomisine 50 binin üzerinde yetişmiş insan gücü kazandırmış ve bir eğitim kurumu olarak ekonomik katkı konusunda üzerine düşen görevini hakkıyla yerine getirdiği tespit edilmiştir. Aynı zamanda sosyal-kültürel ortam açısından bir kültür mozaiği oluşturarak bölgenin dinamik yapısına katkı sağladığı savunulmuştur.

Karataş (2002), "Üniversitelerin Sosyo Ekonomik Gelişmedeki Rolü ve Önemi” adlı tez çalışmasında Muğla Üniversitesi'nin Muğla'nın sosyo-ekonomideki gelişimi incelenerek ele alınmıştır. Sonuç olarak üniversitenin akademik gelişmeye; eğitim-öğretim, akademik faaliyetler, Ar-ge harcamaları, sağlık, ekonomik, kültürel ve danışmanlık gibi işlevlerinin olduğu tespit edilmiştir.

Karakaş (2003-2004), yapmış olduğu çalışmasında Afyon halkının Kocatepe Üniversitesine yönelik yaklaşımını, algılayışını ve beklentisini dikkate alarak, üniversitenin bu beklentileri karşılayıp karşılamadığı sosyolojik açıdan inceleyerek ele almıştır. Sonuç olarak şehir halkının Kocatepe Üniversitesi'nin bölgelerine yaptığı katkının farkında olduğu gözlemlenmiş ve özellikle ekonomik, toplumsal ve kültürel gelişmeye katkısına önem verdikleri tespit edilmiştir.

Gültekin vd. (2008), yapmış oldukları çalışmalarını üniversitelerin şehirlere olan katkıları, toplumsal yapı, istihdam, sanayileşme, nüfus, kentleşme ve sosyal-kültürel yapı başlıkları altında ele almışlardır. Sonuç olarak üniversitelerin sadece bilgi üreten kurumlar olma özelliklerinden ayrılıp özellikle kuruldukları bölgelerde sosyo-kültürel ve ekonomik açıdan birçok katkı yapan kurumlar olduğu ifade edilmiştir.

Taşçı vd. (2011), yapmış oldukları çalışmalarında üniversite öğrencilerinin kente sosyal ve kültürel etkisini ve üniversitenin şehre bütüncül olarak sosyal kültürel etkisini nicel ve nitel yöntemler kullanarak araştırmışlardır. Yapılan araştırma neticesinde Eskişehir halkının büyük bir çoğunluğunun Anadolu Üniversitesi’nin hizmetlerini olumlu olarak gördüğü tespit edilmiştir.

Öztürk vd. (2011), çalışmalarında her ile bir üniversite sloganı ile kurulan ve sayıları gittikçe artan yeni kurulan üniversiteleri ele almışlardır. Üniversitelerin genel olarak ülkenin, özelde ise bulunduğu şehrin sosyoekonomik kalkınmasına katkı sağladığı gerçeğinden hareketle Anadolu'da kurulan üniversitelerin bu katkılarını sosyo-ekonomik açıdan ele alınarak kutuplaşma teorisine göre incelenmiştir. Sonuç olarak üniversitelerin sosyo-ekonomik katkılarının şehrin gelişimine katkı sağlayabilmesi için kurulmadan önce bu ortama uygun ekonomik sosyal/kültürel alt yapının oluşturulması gerektiği ifade edilmiştir.

Sağır ve İnci (2013), Karabük Üniversitesinin Karabük'e olan ekonomik, sosyal ve kültürel açıdan yapmış olduğu katkıları incelemişlerdir. Araştırma sonucunda üniversitenin şehri sosyal, kültürel ve ekonomik açıdan kalkındıran bir görev üstlendiği sonucuna varılmış, üniversitenin halk tarafından benimsendiği görülmüş ve bu doğrultudan hareketle üniversite algısının olumlu olduğu tespit edilmiştir.

Sankır ve Gürdal (2014), üniversitelerin kuruldukları bölgeler için insan kaynakları, bilgi eğitim, istihdam, iş ve sosyal hizmetlerin konusunda çok önemli bir kaynak olduğunu dile getirmişler ve üniversitelerin o şehirlere sayısız katkı sağladığını savunmuşlardır. Çalışmanın sonucunda genel olarak şehir ile üniversite 
arasında olumlu bir etkileşim olduğu halkın üniversiteden ve öğrencilerden memnun olduğu ve üniversitenin şehri büyüme ve gelişme yönünden olumlu olarak etkilediği tespit edilmiştir.

Saatcı vd. (2015), yaptıkları çalışmalarında Bursa'nın Harmancık ilçesindeki meslek yüksekokulunun ilçe halkı tarafından nasıl algılandığını tespit etmeye çalışmışlardır. İlçe halkının meslek yüksekokuluna ilişkin fikirleri ekonomik katkı, bölgesel imaj ve sosyal etki kategorilerinde ele alınarak incelenmiştir. Sonuç olarak bölge halkının üniversiteye bakış açısının olumlu yönde olduğu tespit edilmiştir.

Yavuzçehre (2016), üniversitelerin kuruldukları şehirlere olan demografik, ekonomik, mekânsal, sosyal, kültürel yapıya katkıları ve sanayinin gelişimine etkileri daha geniş bir açıdan ele almış ve Denizli şehri ve Pamukkale üniversitesi özelinde incelemiştir. Araştırma sonucunda Üniversite şehrin kalkınmasında önemli bir aktör olurken aynı şekilde şehir de PAÜ’nün büyümesine ve alt yapının oluşmasına önemli katkılar sağlamıştır.

Uygun vd. (2016), Aksaray ili ve Aksaray Üniversitesi’nin ve öğrencilerinin şehre olan sosyo-ekonomik, kültürel ve çevresel etkilerine yönelik yöre halkının üniversiteye bakış açısını bazı kişisel özelliklere dayandırarak incelemişlerdir. Araştırma sonucunda halkın üniversiteye yönelik algılarında olumsuz durumlar söz konusu olsa da genel olarak yöre halkının üniversite hakkındaki fikirlerinin olumlu olduğu ortaya konulmuştur.

Dursun vd. (2016), büyük şehirlerde kurulmuş köklü üniversitelerin şehrin yalnızca sosyal ve kültürel yönden değil ekonomik, teknolojik ve daha birçok yönden şehrin kendini geliştirmesine katkı sağladığını savunmuşlardır. Araştırma sonucunda Anakara'nın fiziki şartları, şehir yapısı ve belediyecilik hizmetleri açısından olumlu olarak algılanmasa da öğrenciler tarafından, dışa açık, gelişmiş, modern, güvenli ve sakin bir şehir olarak değerlendirilmiştir. Fakat Ankara halkı öğrenciler gözünde çok kötü bir imaj oluşturmuştur.

Arslan (2016), Cumhuriyet Üniversitesi öğrencilerini kapsayan bir araştırma yapmıştır. Çalışmanın temel amacı üniversite öğrencilerinin okudukları şehirlerde şehir ile kurduğu ilişkilerin ekonomik ve sosyal boyutları incelenerek ele alınmıştır. Yapılan araştırma sonucunda tespit edilen sorunların öğrencilerin üniversite tercihi yaparken tercihlerini etkileyecek derecede olduğu tespit edilmiştir.

Sankır vd. (2016), "Zonguldak-Bülent Ecevit Üniversitesi Etkileşimi: Üniversitenin Şehre Olan Etkileri ve Şehrin Üniversite Algısı" adlı çalışmalarında daha önceki çalışmalarından farklı olarak yapmış oldukları anket uygulamasının yanında, STK ve Kamu kurum ve kuruluşları da araştırmaya dahil edilmiş ve daha önce yapılan çalışma çok boyutlu hale getirilmiştir.

Onsekiz ve Atmaca. (2016), üniversite nüfusunun şehre olan etkisini, artan şehir nüfusunun konut sorununu ortaya çıkarmasını, nüfus miktarının yapılan konut sayısındaki değişimlere etkisini, hali hazırdaki konutlarda meydana gelen değişimleri incelemişlerdir.

Küçükçaylı ve Telli, (2017) Burdur ili Ağlasun ilçesinde yaşayan yöre sakinlerinin Ağlasun Meslek Yüksekokuluna yönelik düşüncelerini ekonomik, kültürel, sosyal ve bölgesel imaj açısından tespit etmeye çalışmışlardır. Araştırma sonuçlarından elde edilen verilere göre Ağlasun halkının meslek yüksekokuluna karş1 sosyal etki ve yöresel imaj açısından olumlu düşüncelere sahip olduğu tespit edilmiştir.

Onsekiz (2018) üniversitelerin şehirlere olan etkilerini şehrin hangi bileşenlerinin odağında gerçekleştiğini hangi boyutları ile ele alınarak incelendiğini, inceleme alanının hangi yönde seyrettiğini literatür taraması üzerinden analiz etmiştir. $\mathrm{Bu}$ alanda yapılan çalışmalar araştırılarak üniversite- şehir etkileşimi sosyal, mekânsal ve ekonomik boyutlar üzerinden incelenmiştir. Literatür taraması sonucunda yapılan çalışmaların çoğunun üniversite şehir etkileşiminin ekonomik ve sosyal boyutu ile ilgili olarak ele alındığı görülmüştür.

\section{UYGULAMA}

\subsection{Geliştirilen Hipotezler}

Bu çalışmanın amacı üniversite şehir ilişkisini inceleyerek üniversitelerin şehirlere olan sosyal, kültürel ve ekonomik etkilerini ortaya çıkarmaktır. Bu bağlamda Türkiye'nin en genç üniversitelerinden biri olan Bayburt üniversitesi ve Bayburt ili örnek olarak alınmıştır. Bu kapsamda geliştirilen hipotezler aşağıda sunulmaktadır.

H1: Katılımcıların üniversitenin gelenek ve görenek üzerindeki etkisine yönelik düşünceleri, üniversitenin sosyo-kültürel açıdan etkisine yönelik düşüncelerini anlamlı ve pozitif yönde etkilemektedir.

H2: Katılımcıların üniversitenin ekonomi üzerindeki etkisine yönelik düşünceleri, üniversitenin sosyokültürel açıdan etkisine yönelik düşüncelerini anlamlı ve pozitif yönde etkilemektedir.

H3: Katılımcıların üniversitenin ekonomi üzerindeki etkisine yönelik düşünceleri, üniversitenin gelenek ve görenek açısından etkisine yönelik düşüncelerini anlamlı ve pozitif yönde etkilemektedir.

H4: Katılımcıların üniversitenin sosyo-kültürel açıdan etkisine yönelik düşünceleri, üniversitenin gelenek ve görenek üzerindeki etkisine yönelik düşüncelerini anlamlı ve pozitif yönde etkilemektedir. 
H5: Katılımcıların üniversitenin ekonomi üzerindeki etkisine yönelik düşünceleri, üniversitenin hizmet ve olanaklar üzerindeki etkisine yönelik düşüncelerini anlamlı ve pozitif yönde etkilemektedir.

\subsection{Veri Seti ve Yöntem}

Çalışmanın amaçları, araştırma soruları ve hipotezlerine uygun olarak, tanımlayıcı araştırma yöntemi benimsenmiş ve belirlenen değişkenler ile aralarındaki ilişkilerin birincil veriler kullanılarak ölçümüne karar verilmiştir.

Araştırma için belirlenen anket soruları 3 bölümden oluşmaktadır. İlk bölüm demografik özellikler değişkeni cinsiyet, ikamet süresi, meslek, eğitim, yaş ve katılımcıların aylık geliri gibi değişkenlerden oluşmaktadır. Ankete katılan cevaplayıcıların farklı gruplardan oluşmasına özen gösterilmiş ve kitleyi en iyi şekilde temsil edecek yüksek kabiliyetli bir örneklem oluşmasına dikkat edilmiştir. Anketin ikinci bölümü Bayburt halkının Bayburt Üniversitesi ile olan etkileşimini ölçmeye yönelik sorulardan oluşmaktadır. Anketin son bölümü ise ankete katılan katılımcıların üniversiteye yönelik görüşlerinin ölçüldüğü 5 'li Likert ölçeğine ait önermelerden oluşmaktadır. Bayburt halkı ile üniversite etkileşimine yönelik sorular halkın üniversite hakkında bilgileri, üniversitenin imkânlarından yararlanma, üniversite hakkında hangi kaynaklardan bilgi edinme ve üniversiteden beklentilerini ölçmeye yarayan sorulardan oluşmaktadır.

Araştırmada kullanılan anket soruları literatürde geçerlilik ve güvenirlikleri önceden tespit edilmiş $\mathrm{H}$. Sankır, E. Dirimeşe, A. Barutçu, F. Özdemir (2016) ve D. Taşçı, E. Gökalp, E, Genç Kumtepe, A. T. Kumtepe. E, Toprak, B, T. Tosunoğlu, (2011) çalışmaları incelenerek hazırlanmıştır. Anketin ilk bölümünde yer alan sosyo-ekonomik, kültürel ve demografik sorular Sankır vd.' (2016) çalışmasından alınmıştır. İkinci bölümde kullanılan anket soruları Taşvı vd. (2011) ile yine Sankır vd (2016) çalışmaları arasından benzer sorular seçilerek katılımcıların üniversite hakkındaki düşünceleri önermeler temelindeki toplumsal değişim potansiyelleri açısından ekonomik, nüfus, sosyo-kültürel, gelenek ve görenek, hizmet ve olanaklar ve çevresel değişimler gibi altı farklı açıdan ele alınıp hazırlanmıştır. Anket toplam 22 soru ve 47 önermeden oluşmaktadır.

Anket çalışması üniversitenin ana yerleşkesi olan Dede Korkut Külliyesi’nin bulunduğu esnafın yoğun olduğu yerlerde ve Genç Osman Mahallesi, Zahit Mahallesi Esentepe Mahallesi gibi yerleşkeye yakın olana mahallelerde ulaş1lan 500 kişiye uygulanmıştır. Bu bölgelerin seçilmesindeki temel amaç üniversite- şehir ilişkisinin yaşandığı yoğun bölgeler olmasıdır. Daha önceden tespit edilen sayıda anket, yukarıda bahsedilen örneklem gruplarına uygulanmıştır.

\section{BULGULAR}

Araştırmanın sonuçlarına göre demografik özelliklere yönelik birçok veri toplanmıştır. Burada araştırmanın etkileri açısından en önemli olduğu düşünülen özellikler sunulmuştur.

Araştırmaya katılanların eğitim durumlarına bakıldığında \%55nin (220) üniversite mezunu oldukları, geri kalan bölümünün sırasıyla 27,8 (111) lise, ilkokul \%7sini (23) ortaokul \%5,8 ini (23) ve \%4,5 ini (18) Lisansüstü katılımcılar oluşturmaktadır. Ankete katılanların yarısından fazlasının lisans mezunu olduğu görülmektedir.

Ankete katılan bireylerin gelir durumuna bakıldığında birinci sırada \%16,5 (66) ile 1500-2000 TL arası, ikinci sırada \%13,8 (55) ile 3001-3500 TL arası, üçüncü sırada \%12 (48) ile 2001-2500 TL arası gelire sahip olanların geldiği görülmektedir. 500-1000 TL arası gelir ise \% 4,5 (18) oranla son sırada yer almaktadır. Tabloya bakıldığında katılımcıların çoğunluğunu orta gelir grubunun oluşturduğu görülmektedir.

Çalışmada katılımcıların, ankette yer alan sorular birbirinden bağımsız değerlendirip/değerlendiremediklerini ortaya koymak amacıyla Ki-kare analizi yapılmıştır (Kavak, 2013: 252). Ki-kare analizi sonuçlarına göre, katılımcıların cevap seçeneklerini $\% 95$ güvenilirlik düzeyinde anlamlı olarak birbirlerinden ayırt ettikleri söylenebilmektedir.

\subsection{Güvenilirlik Analizi}

Çalışmada kullanılan ölçeklerin güvenilirliklerinin test edilmesinde Cronbach alfa değerleri hesaplanarak incelenmiştir. Cronbach alfa sonuçları Tablo 1'de, sunulmaktadır. Sosyal bilimlerdeki araştırmalarda Cronbach alfa değerinin kabul edilebilir aralığ genel olarak 0.70-0.95 aralığı kabul edilmektedir (Nunnally ve Bernstein, 1994; Hair vd., 2010: 125 ). Ancak Cronbach alfa değeri, ölçekte yer alan madde sayısından ve örneklem sayısından önemli ölçüde etkilenmektedir. Ölçekte yer alan ifade sayısı arttıkça Cronbach alfa değeri de artma eğilimi göstermektedir (Nunnally ve Bernstein, 1994; Streiner, 2003). Bu kapsamda baz1 araştırmacılar kabul edilir değeri 0.50 olduğunu ifade etmektedir (George ve Mallery, 2003; DeVellis, 2011).

Çalışmada kullanılan ölçekte farklı özellikleri ölçen 47 soru katılımcılara yöneltilmiştir. Sorulara ilişkin Ekonomik özellikler için "EKO" nüfus özellikleri için "NFS", sosyal kültürel özellikler için "SK" gelenek 
görenek özellikleri için "GG” hizmet ve olanaklara ilişkin özellikler için "HVO” ve çevresel özelliklere ilişkin olarak "CD" kodları belirlenmiştir.

\subsection{Güvenirlik Analizi Sonuçları}

Tablo 1'de görüldüğü üzere, ekonomik özellikler (0.714), sosyal kültürel özellikler (0.755), hizmet ve olanaklara ilişkin özellikler (0.718) ile ilgili ölçeklerin Cronbach değerlerinin önerilen 0.70 değerinin üzerindedir (Hair vd., 2010: 125). Çevresel özellikler ile ilgili ölçeğin değeri (0.643) de kabul edilebilir aralıkta olduğu söylenebilmektedir. Diğer taraftan nüfus özellikleri (0.471) ve gelenek görenek özellikleri (0.496) ölçeklerinin Cronbach alfa değerlerinin önerilen değerin altında olduğu tespit edilmiştir.

\section{Tablo 1}

\begin{tabular}{|l|c|}
\hline Ölçek & Cronbach Alfa \\
\hline EKO &, 714 \\
\hline NFS & $\mathbf{, 4 7 1}$ \\
\hline SK &, 755 \\
\hline GG & $\mathbf{, 4 9 6}$ \\
\hline HVO &, 718 \\
\hline CD & $\mathbf{, 6 4 3}$ \\
\hline
\end{tabular}

\subsection{Frekans Analizi Bulguları}

Araştırmanın sonuçlarına göre frekans analizi bulgularına yönelik birçok veri toplanmıştır. Burada araştırmanın etkileri açısından en önemli olduğu görülen özelliklere yer verilmiştir.

Tablo 2. Bayburt Üniversitesi’nden beklentileriniz nelerdir?

\begin{tabular}{|l|c|c|}
\hline & $\mathbf{n}$ & $\%$ \\
\hline Yaptığı bilimsel çalışmalarla şehrin adını duyurması & 167 & 41,8 \\
\hline Şehrin imajına katkı sağlaması & 150 & 37,5 \\
\hline Yerel yönetimlerle daha çok işbirliği yaparak şehrin gelişimine katkıda bulunması & 160 & 40 \\
\hline Şehrin temel sorunlarına yönelik politikalar üretmesi & 130 & 32,5 \\
\hline Şehre daha çok öğrenci çekmesi & 106 & 26,5 \\
\hline Üniversite bünyesinde daha çok iş olanağı sağlaması & 88 & 22 \\
\hline Türkiye'nin sayılı üniversiteler arasına girmesi & 147 & 36,8 \\
\hline Daha çok sanatsal, sportif, sosyal ve kültürel etkinlikler düzenlemesi & 119 & 29,8 \\
\hline
\end{tabular}

Ankete katılan katılımcıların bu soruya vermiş oldukları cevapların dağılımına bakıldığında; birinci sırada \%41 (167) ile Yaptığı bilimsel çalışmalarla şehrin adını duyurması cevabını verdiklerini, bunu takiben \%40 (160) ile Yerel yönetimlerle daha çok işbirliği yaparak şehrin gelişimine katkıda bulunması, \% (150) ile Şehrin imajına katkı sağlaması cevabı geldiği ve bunu diğer yanıtların takip ettiği görülmektedir. Üniversite bünyesinde daha çok iş olanağı sağlaması cevabı ise \% 22 (88) ile son sırada yer almaktadır.

Tablo 3. Üniversite tarafından daha çok hangi konularda ne tür etkinliklerin gerçekleştirilmesini istersiniz?

\begin{tabular}{|c|c|c|}
\hline & $\mathbf{n}$ & $\%$ \\
\hline Bilimsel konferanslar, sempozyumlar, toplantılar & 138 & 34,5 \\
\hline $\begin{array}{l}\text { Bayburt ilinin sorunlarına, sosyo-ekonomik ve sosyo-kültürel gelişimine ve tanıtımına yönelik } \\
\text { çalışmalar }\end{array}$ & 181 & 45,3 \\
\hline
\end{tabular}




\begin{tabular}{|l|c|c|} 
Bayburt halkının ihtiyaç duyduğu konularda, eğitim ya da bilgilendirici toplantılar ve kurslar & 142 & 35,5 \\
\hline $\begin{array}{l}\text { Bayburt halkının ve BÜ öğrencilerinin ihtiyaçlarına yönelik sosyal, külttürel, sanatsal ve sportif } \\
\text { etkinlikler }\end{array}$ & 119 & 29,8 \\
\hline Üniversitenin geliştirilmesi ve başarısının arttırılmasına ve tanıtılmasına yönelik çalışmalar & 130 & 32,5 \\
\hline $\begin{array}{l}\text { Sağlık alanında halkın bilinçlenmesini sağlayacak ücretsiz sağlık taraması veya toplantılar gibi } \\
\text { çalışmalar }\end{array}$ & 73 & 18,3 \\
\hline
\end{tabular}

Ankete katılan kişilerin bu soruya vermiş oldukları cevapların oranına bakıldığında \%45,3 (181) ile Bayburt ilinin sorunlarına, sosyo-ekonomik ve sosyo-kültürel gelişimine ve tanıtımına yönelik çalışmalar cevabı ilk sırada, \%35,5 (142) ile Bayburt halkının ihtiyaç duyduğu konularda, eğitim ya da bilgilendirici toplantılar ve kurslar cevabı ikinci sırada, bilimsel konferanslar, sempozyumlar, toplantılar cevabı ise üçüncü sırada yer aldığı diğer cevapların bunları takip ettiği görülmektedir. En düşük oran olan \%18,3 (73) ile sağlık alanında halkın bilinçlenmesini sağlayacak ücretsiz sağlık taraması veya toplantılar gibi çalışmalar cevabı son sırada yer almaktadir.

\subsection{Regresyon Analizi Bulguları}

Belirlenen hipotezler doğrultusunda katılımcıların özelliklerine yönelik regresyon analizleri yapılmıştır.

Tablo 4. Tahmin edilen modele ilişkin istatistikler

\begin{tabular}{|c|c|c|c|c|}
\hline Model & R & R kare & Düzeltilmiş R kare & Tahminin standart hatası \\
\hline 1 & $.557^{\mathrm{a}}$ & .310 & .307 & .62911 \\
\hline
\end{tabular}

a. Tahminci: (Sabit), YORTGG, ORTEKO

b. Bağımlı Değişken: ORTSK

Regresyon analizi bulgularına göre modelin düzeltilmiş determinasyon katsayısı $R^{2}=0,307$ olarak hesaplanmıştır. Sosyo kültürel faaliyetlere ilişkin değişimlerin yaklaşık yüzde 31 lik bir kısmı ekonomik ve gelenek görenek özellikleri tarafından açıklanmaktadır.

Regresyon modeli topluca katsayı anlaml111k testi olan $F$ testi ile $(F=89,175 p<0,05)$ ile modelin anlaml olduğu tespit edilmiştir. Ayrıca, varyans şişirme faktörü (VIF) istatistiklerine bakıldığında çoklu doğrusallık sorununun olmadığı görülmektedir.

Tablo 5. Tahmin edilen modele iliş̧kin değişken katsayıları

\begin{tabular}{|c|c|c|c|c|c|c|c|c|}
\hline & \multirow[t]{2}{*}{ Model } & \multicolumn{2}{|c|}{$\begin{array}{c}\text { Standartlaştırılmamış } \\
\text { katsayılar }\end{array}$} & \multirow{2}{*}{\begin{tabular}{|c|c}
$\begin{array}{c}\text { Standart } \\
\text { katsayılar }\end{array}$ \\
Beta \\
\end{tabular}} & \multirow[t]{2}{*}{$\mathbf{t}$} & \multirow[t]{2}{*}{ Anlamlılık. } & \multirow[b]{2}{*}{ Tolerance } & \multirow[b]{2}{*}{ VIF } \\
\hline & & B & Std. Hata & & & & & \\
\hline \multirow{3}{*}{1} & (Sabit) & .764 & .198 & & 3.854 & .000 & & \\
\hline & ORTEKO & .142 & .041 & .152 & 3.462 & .001 & .906 & 1.104 \\
\hline & YORTGG & .655 & .058 & .491 & 11.210 & .000 & .906 & 1.104 \\
\hline
\end{tabular}

a. Bağımlı Değişken: ORTSK

Bağımsız değişken katsayılarına bakıldığında her iki katsayının da pozitif ve $\mathrm{p}<0,01$ düzeyinde anlamlı olduğu görülmektedir. Katılımcıların ekonomik özelliklere ilişkin düşüncelerindeki pozitif yönlü değişimler sosyo kültürel özelliklere ilişkin düşüncelerinin de pozitif yönlü olarak değişmesine neden olmaktadır. Benzer şekilde katılımcıların gelenek görenek özelliklerine ilişkin düşüncelerindeki pozitif yönlü değişimler sosyo kültürel özelliklere ilişkin düşüncelerinin de pozitif yönlü olarak değişmesine neden olmaktadır.

Tablo 6. Tahmin edilen modele ilişkin istatistikler

\begin{tabular}{|l|l|l|l|l|}
\hline \multicolumn{1}{|c|}{ Model } & \multicolumn{1}{|c|}{ R } & \multicolumn{1}{c|}{ R kare } & Düzeltilmiş R kare & Tahminin standart hatası \\
\hline 1 &, $559^{\mathrm{a}}$ &, 312 &, 309 &, 47091 \\
\hline
\end{tabular}

a. Tahminci: (Sabit), ORTEKO, ORTSK 
Regresyon analizi bulgularına göre modelin düzeltilmiş determinasyon katsayısı $\mathrm{R}^{2}=0,309$ olarak hesaplanmıştır. Gelenek görenek özelliklerine ilişkin değişimlerin yaklaşık yüzde 31 lik bir kısmı ekonomik ve sosyo-kültürel özellikler tarafından açıklanmaktadır.

Regresyon modeli topluca katsayı anlaml1lık testi olan $F$ testi ile $(F=90,091 p<0,05)$ ile modelin anlaml1 olduğu tespit edilmiştir. Ayrıca, varyans şişirme faktörü (VIF) istatistiklerine bakıldığında çoklu doğrusallık sorununun olmadığı görülmektedir.

Tablo 7. Tahmin edilen modele ilişkin değişken katsayıları

\begin{tabular}{|c|c|c|c|c|c|c|c|c|}
\hline & \multirow[t]{2}{*}{ Model } & \multicolumn{2}{|c|}{$\begin{array}{c}\text { Standartlaştırılmamış } \\
\text { katsayılar }\end{array}$} & $\begin{array}{c}\text { Standart } \\
\text { katsayılar }\end{array}$ & \multirow[t]{2}{*}{$\mathbf{t}$} & \multirow[t]{2}{*}{ Anlamlılık. } & \multirow[b]{2}{*}{ Tolerance } & \multirow[b]{2}{*}{ VIF } \\
\hline & & B & Std. Hata & Beta & & & & \\
\hline \multirow{3}{*}{1} & (Sabit) & 1,518 &, 130 & & 11,637 &, 000 & & \\
\hline & ORTSK & 367 &, 033 &, 490 & 11,210 &, 000 &, 908 & 1,101 \\
\hline & ORTEKO &, 112 &, 031 & ,159 & 3,645 &, 000 & ,908 & 1,101 \\
\hline
\end{tabular}

a. Bağımlı değişken: YORTGG

Bağımsız değişken katsayılarına bakıldığında her iki katsayının da pozitif ve $\mathrm{p}<0,01$ düzeyinde anlamlı olduğu görülmektedir. Katılımcıların sosyo-kültürel özelliklere ilişkin düşüncelerindeki pozitif yönlü değişimler gelenek görenek özelliklerine ilişkin düşüncelerinin de pozitif yönlü olarak değişmesine neden olmaktadır. Benzer şekilde katılımcıların ekonomik özelliklere ilişkin düşüncelerindeki pozitif yönlü değişimler de gelenek görenek özelliklerine ilişkin düşüncelerinin de pozitif yönlü olarak değişmesine neden olmaktadır.

Tablo 8. Tahmin edilen modele ilişkin istatistikler

\begin{tabular}{|c|c|c|c|c|}
\hline Model & R & R kare & Düzeltilmiş R kare & Tahminin standart hatası \\
\hline 1 &, $204^{\text {a }}$ &, 042 &, 039 &, 54847 \\
\hline
\end{tabular}

a. Tahminci: (Sabit), ORTEKO

Regresyon analizi bulgularına göre modelin düzeltilmiş determinasyon katsayısı $\mathrm{R}^{2}=0,039$ olarak hesaplanmıştır. Hizmet ve olanaklara ilişkin değişimlerin yaklaşık yüzde 4 lük bir kısmı ekonomik özellikler tarafından açıklanmaktadır.

Regresyon modeli topluca katsayı anlaml111k testi olan $F$ testi ile $(F=17,247 p<0,05)$ ile modelin anlaml olduğu tespit edilmiştir. Ayrıca, varyans şişirme faktörü (VIF) istatistiklerine bakıldığında çoklu doğrusallık sorununun olmadığ görülmektedir.

Tablo 9. Tahmin edilen modele iliş̧kin değişken katsayıları

\begin{tabular}{|c|c|c|c|c|c|c|c|c|}
\hline \multirow{2}{*}{\multicolumn{2}{|c|}{ Model }} & \multicolumn{2}{|c|}{$\begin{array}{c}\text { Standartlaştırılmamış } \\
\text { katsayılar }\end{array}$} & \multirow{2}{*}{$\begin{array}{c}\begin{array}{c}\text { Standart } \\
\text { katsayılar }\end{array} \\
\text { Beta }\end{array}$} & \multirow[t]{2}{*}{$\mathbf{t}$} & \multirow[t]{2}{*}{ Anlamlılık. } & \multirow[b]{2}{*}{ Tolerance } & \multirow[b]{2}{*}{ VIF } \\
\hline & & B & Std. Hata & & & & & \\
\hline \multirow{2}{*}{1} & (Sabit) & 2,552 &, 124 & & 20,637 &, 000 & & \\
\hline & ORTEKO &, 141 &, 034 & ,204 & 4,153 &, 000 & 1,000 & 1,000 \\
\hline
\end{tabular}

a. Bağımlı değişken: ORTHVO

Bağımsız değişken katsayılarına bakıldığında pozitif ve $\mathrm{p}<0,01$ düzeyinde anlamlı olduğu görülmektedir. Katılımcıların ekonomik özelliklere ilişkin düşüncelerindeki pozitif yönlü değişimler hizmet ve olanak özelliklerine iliş̧kin düşüncelerinin de pozitif yönlü olarak değişmesine neden olmaktadır. 


\section{Tablo 10. Hipotez Kabul/Red Durum Değerlendirilmesi}

\begin{tabular}{|l|l|}
\hline $\begin{array}{l}\text { H1: Katılımcıların üniversitenin gelenek ve görenek üzerindeki etkisine yönelik düşünceleri, üniversitenin } \\
\text { sosyo kültürel açıdan etkisine yönelik düşüncelerini anlamlı ve pozitif yönde etkilemektedir. }\end{array}$ & Kabul \\
\hline $\begin{array}{l}\text { H2: Katılımcıların üniversitenin ekonomi üzerindeki etkisine yönelik düşünceleri, üniversitenin sosyo } \\
\text { kültürel açıdan etkisine yönelik düşüncelerini anlamlı ve pozitif yönde etkilemektedir. }\end{array}$ & Kabul \\
\hline $\begin{array}{l}\text { H3: Katılımcıların üniversitenin ekonomi üzerindeki etkisine yönelik düşünceleri, üniversitenin gelenek ve } \\
\text { görenek açısından etkisine yönelik düşünceleri anlamlı ve pozitif yönde etkilemektedir. }\end{array}$ & Kabul \\
\hline $\begin{array}{l}\text { H4: Kattlımcıların üniversitenin sosyo kültürel açıdan etkisine yönelik düşünceleri, üniversitenin gelenek ve } \\
\text { görenek üzerindeki etkisine yönelik düşünceleri anlamlı ve pozitif yönde etkilemektedir. }\end{array}$ & Kabul \\
\hline $\begin{array}{l}\text { H5: Katılımcıların üniversitenin ekonomi üzerindeki etkisine yönelik düşünceleri, üniversitenin hizmet ve } \\
\text { olanaklar üzerindeki etkisine yönelik düşünceleri anlamlı ve pozitif yönde etkilemektedir. }\end{array}$ & Kabul \\
\hline
\end{tabular}

\section{SONUC}

Üniversitelerin bulundukları bölgenin ya da şehrin kalkınmasında yaşamsal olan faydaları günümüzde kesinlik kazanmış unsurlar olarak öne çıkmaktadır. Üniversiteler artık görevlerinin dışına çıkıp bulundukları bölgelere ekonomik, sosyo-kültürel, çevresel bir canlılık getirmektedir. Çalışmada ele alıp incelenen konularda üniversitelerin gelişiminin içinde bulundukları şehirlerin cazibesinin artışına önemli katkılar sağladığı görülmüştür

Üniversitelerin bilim yuvası olduğu noktasından hareketle Bayburt Üniversitesi'nin yapmış olduğu bilimsel çalışmalardan memnun olmakla beraber Bayburt halkı üniversiteden daha çok bilimsel çalışma yapılmasını istemektedir. Bu beklentinin Üniversitenin yaptığı bilimsel çalışmalarla şehrin adını duyurması, yerel yönetimlerle daha çok işbirliği yaparak şehrin gelişimine katkıda bulunması ve şehrin imajına katkı sağlaması ile Türkiye'nin sayılı üniversiteler arasına girmesi üzerine yoğunlaştığı görülmektedir. Bu durum halkın Bayburt'a sahip çıktığını göstermekte ve üniversiteyi şehrin tanıtımına, gelişimine ve sorunlarına çare olacak bir araç olarak gördüğünü göstermektedir. Bu durum halk ile üniversitenin etkileşimi açısından dikkate alınacak bir değerlendirmedir.

Bayburt halkının üniversitenin büyümesi sayesinde Bayburt'un da büyüyüp geliştiğinin ve üniversitenin yurt içinde ve yurt dışı tanıtımına önemli katkılar sağladığının farkında oldukları anlaşılmaktadır. Bununla beraber üniversiteye yeni bölümlerin açılması ve öğrenci sayılarının arttırılmasına yönelik beklentilerin yüksek olduğu tespit edilmiştir.

Halkın beklentilerine yönelik üniversitede açılacak fakülte ve bölümlerin bölgenin ön planda ve avantajlı olduğu alanlara yönelik açılması, hem o şehirdeki öğrenciler için tercih sebebi hem de diğer öğrencilere farklı alternatif olması açısından tercih nedeni olabilir. Ayrıca bu beklentiler karşılanmaya çalışılırken sadece bu istekler dikkate alınmamalı ve daha objektif gerçekler doğrultusunda hareket edilmelidir. Açılacak bölümler doğrultusunda öğrenci sayısındaki artışın getireceği etkiler de dikkate alınmalı ve bu öğrencilerin oluşturacağı taleplerin önceden tespit edilerek önlem alınması gerekmektedir.

Bayburt halkının sosyo-ekonomik ve sosyo-kültürel gelişimine ve tanıtımına yönelik çalışmalar beklemesi, ihtiyaç duydukları konularda, eğitim ya da bilgilendirici toplantılar ve kurslar düzenlemesini istemesi, halkın üniversiteyi kendi ihtiyaçlarını giderecek bir kurum olarak görmesi anlamına gelmektedir. Bu beklentiler üniversiteyi halkın gözünde önemli bir araç olduğunu göstermektedir. Bu nedenle Bayburt Üniversitesi halkın ihtiyaçları doğrultusunda daha çok sosyal, kültürel ve bilimsel faaliyetler düzenlemeli ve halkı daha çok bünyesine katmaya çalışmalıdır. Şehir halkına yönelik, eğitimler verilmeli, sertifika programları düzenlemeli ve sosyal yaşama katacak farklı aktiviteler oluşturulmalıdır. Bunları yaparken halkın beklentileri dikkate alınmalı ve bu faaliyetleri duyurmada üniversite daha fazla çaba göstermelidir. Bu konuda yerel basın ile ve diğer bölgesel aktöreler ile daha çok işbirliği yaparak şehir halkına daha çok ulaşılması gerektiği ortaya çıkmaktadır.

Bayburt Üniversitesi'nin şehrin ekonomik hayatına çok önemli katılar sağladığı şehir ekonomisini canlandırdığı anlaşılmaktadır. Bunun paralelinde yeni iş yerlerinin açılması, yeni konutların yapılması, pansiyon ve konut sayısının artması şehre ekonomik yönden ayrı bir ivme kazandırmıştır.

Bayburt Üniversitesi'ne ülkenin farklı şehirlerinden gelen öğrencilerin ortaya koymuş oldukları kültürel farklılıkları sosyal yaşama olumlu katkılar sunarak demokratik ve hoşgörüye dayalı bir ortamın oluşmasını sağlamıştır. Üniversitenin halk ile öğrencileri kaynaştıııcı ortamların oluşmasını sağladığı halkın farklı kültürleri tanıma imkânı bulduğu anlaşılmaktadır 
Tüm değerlendirmeler doğrultusunda bölgesel değişim hareketleri bağlamında Bayburt Üniversitesinin Bayburt'a sosyal, kültürel, ekonomik ve bilimsel olarak fayda sağladığı, üniversitenin gelişmesi ile birlikte şehrin de büyüyüp geliştiği görülmüştür.

$\mathrm{Bu}$ çalışma üniversitenin kültürel, sosyal ve ekonomik etkisine yönelik bir araştırma olduğu gibi aynı zamanda halkla ilişkilere yönelik bir araştırmadır. Bayburt Üniversitesi'nin şehre olan etkileri tek yönlü olmayıp karşılıklı bir ilişkinin sonucu olarak ortaya çıkmaktadır.

Sonuç olarak bu çalışma Türkiye'nin en küçük ili olan Bayburt'ta gerçekleştirilmiştir. Bayburt Üniversitesi'nin de yeni kurulan butik bir üniversite olması sebebi ile üniversitenin şehre olan etkileri büyük şehirlerde kurulan üniversitelerin etkilerinden daha farklı olabilecektir. Bayburt ekonomisinin önemli bir kısmının üniversiteye bağlı olarak gerçekleştiği bilinmektedir. Dolayısıyla Bayburt şehrinin üniversiteden beklentileri de bu ölçüde büyüktür. Bu nokta çalışmanın sınırlılıklarından biri olarak düşünülebilir. Bu sebeple büyük şehirlere yönelik yapılan çalışmalar için bu sonuçlar farklılık arz edebilir ve daha önemli sonuçlar ortaya koyabilir. 


\section{KAYNAKÇA}

Acar, Günseli ve Özbekler, Müge Türkan, (2019). “Üniversite Öğrencilerinin İlçe Ekonomisine Katkıları: Sinop Üniversitesi Ayancık Meslek Yüksekokulu Örneği’’. Sinop Üniversitesi Sosyal Bilimler Dergisi, 3 (1): 33-54.

Akçakanat, Tahsin ve diğ.,(2011). "Süleyman Demirel Üniversitesi Öğrencilerinin Isparta'da Ki Yaşam Kalitesi ve Isparta Halkına İlişkin Tutumların Değerlendirilmesi”. Süleyman Demirel Üniversitesi Vizyoner Dergisi. 3.(4). 118.

Arslan, Fatih, (2016). “Üniversite Öğrencilerinin Şehirle Kurduğu Ekonomik ve Sosyal İlişkilerden Memnuniyet Analizi: Sivas Cumhuriyet Üniversitesi Örneği”. İnsan ve Toplum Bilimleri Araştırmaları Dergisi. Cilt:5. Sayı:4. 11031120.

Aslan, İsmail ve Sırrım, Veli, (2019). “Tekirdağ Namık Kemal Üniversitesi’nin Süleymanpaşa İlçesinin Ekonomik Gelişimi Üzerindeki Etkileri: Öğrenci Tüketim Harcamaları Özelinde Bir Değerlendirme”. Balkan Sosyal Bilimler Dergisi. 8(15) 61-76.

Atik, Hayriye, (1999). "Üniversitelerin Yerel Ekonomiye Katkıları: Teori ve Erciyes Üniversitesi Üzerine Bir Uygulama”. Erciyes Üniversitesi İktisadi ve İdari Bilimler Dergisi. Sayı:15.99-109.

Çalışkan, Şadan, (2010). "Üniversite Öğrencilerinin Harcamalarının Kent Ekonomisine Katkısı. (Uşak Üniversitesi Örneği)". Elektronik Sosyal Bilimler Dergisi. 9. (31). 169-179.

Çınar, Recai ve Emsen, Selçuk. (2001). "Eğitim ve İktisadi Gelişme: Atatürk Üniversitesi'nin Erzurum İl Ekonomisi ve Sosyal Yapısı Üzerindeki Etkileri”. İktisadi ve İdari Bilimler Dergisi. Cilt:15. Sayı: 1-2. 91-104.

Demireli, Cemalettin ve Taşkın, Ercan, (2013). "Üniversite Öğrencilerinin Bulundukları Şehre Ekonomik Katkıları: Kütahya İl Merkezi Örneği’’. Dumlupınar Üniversitesi Sosyal Bilimler Dergisi. Sayı: 37.

DeVellis, Robert. F. (2011). "Scale Development: Theory and Applications. Thousand Okas, CA: SAGE Publications.

Dursun, İbrahim ve diğg. (2016). "Üniversite Öğrencilerinin Şehir ve Güvenlik Algısı”. Güvenlik Çalışmaları Dergisi. 18 (2). 1-23.

Erkekoğlu, Hatice, (2000). "Bölge Üniversitelerinin Yerel Ekonomiye Katkıları: Sivas Cumhuriyet Üniversitesi Örneği”. Erciyes Üniversitesi İktisadi ve İdari Bilimler Dergisi, 16. 211-229.

George, Darren ve Mallery, Paul, (2003). SPSS for Windows Step by Step: A Simple Guide and Reference. Boston: Allyn \& Bacon.

Geçikli, Fatma, (2008). Halkla İlişkiler ve İletişim.Beta Basım Yayım Dağıtım A.Ş. İstanbul.

Görkemli, Nur Hayriye, (2009). “Selçuk Üniversitesi’nin Konya Kent Ekonomisine Etkileri”. Selçuk Üniversitesi Sosyal Bilimler Enstitüsü Dergisi, Sayı:22. 169-189.

Gültekin, Nihat ve diğ., (2008). "Üniversitelerin Kuruldukları Kente Katkıları". Elektronik Sosyal Bilimler Dergisi. C.7. S.24. 264-269.

Gürkaynak, R, Mehmet ve Kasımoğlu Murat, (2004). “Türkiye'de Üniversite-Komşu Çevre Etkileşimi”, İşbirliği İçin Bir Ön Çalışma. Amme İdaresi Dergisi, 37 (3). 147-162.

Hair, Joseph F, et. al, (2010). Multivariate Data Analysis. Amerika Birleşik Devletleri: Pearson.

Karataş, Muhammed (2002). "Üniversitelerin Sosyo-Ekonomik Gelişmedeki Rolü ve Önemi (Muğla Üniversitesi Örneği)", Yayınlanmamış Doktora Tezi. Muğla Üniversitesi Sosyal Bilimler Enstitüsü. Muğla.

Kavak, Bahtışen, (2013). Pazarlama ve Pazar Araştırmaları/Tasarım ve Analiz (1 b.). Detay Yayıncılık. Ankara.

Köksal, Samet ve diğ., Üniversitelerin Bulundukları Şehirlere Ekonomik Katkıları Üzerine Bir Literatür Değerlendirmesi. Erişim: https://www.academia.edu/9065493/\%C3\%9CN\%C4\%B0VERS\%C4\%B0TELER\%C4\%B0N_BULUNDUKLA RI_\%C5\%9EEH\%C4\%B0RLERE_EKONOM\%C4\%B0K_KATKILARI_\%C3\%9CZER\%C4\%B0NE_B\%C4\% B0R_L\%C4\%B0TERAT\%C3\%9CR_DE\%C4\%9EERLEND\%C4\%B0RMES\%C4\%B0

Küçükçaylı, Fatma Mumcu ve Telli, Eda (2017). " Yöre Halkının Üniversite Algısı: Ağlasun Meslek Yüksekokulu Örneği. Mehmet Akif Ersoy Üniversitesi. Sosyal Bilimler Enstitü Dergisi. Cilt:9. Sayı:21 (Özel Say1).

Nunnally, Jum. C. and Bernstein, Ira. H (1994). Psychological theory. MacGraw-Hill.

Onsekiz, Dilşen ve Atmaca, İlker (2016). "Öğrencileşen Kentlerde Konut Sorununun Yeniden Tanımlanması: Uşak Kenti Örneği”. 4. Uluslararası Kentsel ve Çevresel Sorunlar ve Politikalar Kongresi, 20-22 Ekim 2016, İstanbul, Türkiye, Oturum IX A, Kentsel Hizmetler ve Kalkınma. 650-661.

Onsekiz, Dilşen, (2018). "Üniversitelerin Anadolu Kentlerine Etkileri: Bir Literatür Taraması". Uluslararası Sosyal Araştırmalar Dergisi Cilt: 11, Sayı: 55, 400-405.

Özbay, Özden, (2013). "Üniversite ve Sosyal Çevresi: Niğde Üniversitesi ve Niğde”. Ankara Üniversitesi Sosyal Bilimler Dergisi.4(1) DOI:10. 1-63.

Öztürk Salih ve diğ., (2011). "Anadolu'da Kurulan Üniversitelerin İllerin Sosyo-Ekonomik Yapılarına Katkıları". Mustafa Kemal Üniversitesi Sosyal Bilimler Enstitüsü Dergisi. 8 (16). 145-158.

Saatcı, Gencay ve diğ. (2015). "Yerel Halkın Ünđversđteye Bakış Açısı: Harmancık Meslek Yüksekokulu Örneğì". Akademik Bakış Dergisi. Say: 47.

Sağır, Adem ve İnci, Ülkü (2013). "Karabük’te Üniversite Algısı: Karabük Üniversitesi Örneği’’. İnsan ve Toplum Bilimleri Araştırmaları Dergisi. Cilt.2, Sayı: 2.51-81.

Sankır Hasan ve Gürdal Demir A.(2013). Bülent Ecevit Üniversitesi'nin Zonguldak’a Etkileri ve Şehrin Üniversite Algısı. Bülent Ecevit Üniversitesi Yayınları, Orient Yayıncılık Reklamcılık Araştırma, Ankara. 
Sankır Hasan. Gürdal Demir Ayça, (2014). “Bülent Ecevit Üniversitesi’nin Zonguldak’a Etkileri ve Kentin Üniversite Algısı". Yükseköğretim ve Bilim Dergisi. Cilt:4. Sayı:2. 90-98.

Sankır, Hasan ve diğ., (2016) "Zonguldak-Bülent Ecevit Üniversitesi Etkileşimi: Üniversitenin Şehre Etkileri ve Şehrin Üniversite Algısı" Bülent Ecevit Üniversitesi Yayınları No: 10. Mattek Matbaacılık Basım Yay. Ankara.

Sargın, Sevil, (2007). “Türkiye’de Üniversitelerin Gelişim Süreci ve Dağılımı”. Süleyman Demirel Üniversitesi Sosyal Bilimler Enstitüsü Dergisi Y11:3 Say1:5. 113-150.

Streiner, David, L, (2003). "Starting at the Beginning: An Introduction to Coefficient Alpha and Internal Consistency". Journal of Personality Assessment, 80(1), 99-103.

Uygun, Mutlu ve diğ., (2016). “Üniversitenin Kente Olan Ekonomik, Sosyo-Kültürel ve Çevresel Etkilerine Yönelik Yerel Halk Algıs1", Aksaray Üniversitesi İktisadi ve İdari Bilimler Fakültesi Dergisi.8 (4).66-85.

Taşç1, Deniz ve diğ., (2011). "Kentin Üniversite Algısı: Anadolu Üniversitesi ve Eskişehir Örneği”. Amme İdaresi Dergisi. Cilt:44. Sayı: 2. 131-146.

Tösten, Rasim ve dĭg., (2013). “Dicle Üniversitesi Öğrencilerinin Harcama Analizi Ve Diyarbakır Ekonomisine Katk1s1”. Dicle Üniversitesi Sosyal Bilimler Enstitüsü Dergisi. Y1l:5 S.10.

Torun, İshak ve diğ., (2009). "Yöre Halkının Üniversiteye Bakışı ve Beklentileri: Kars Kafkas Üniversitesi Örneği”". Sosyal Bilimler Dergisi. Sayı:21. 169-188.

Torun İshak ve Öztürk Salih, (2013). "Yükseköğrenimin Etkinleştirilmesi ve Taşra Üniversitelerinin Önemi”. Atatürk Üniversitesi İktisadi ve İdari Bilimler Dergisi, Cilt:27. Say1:1.197-208.

Yavuzçehre, Savaş Pınar,(2016). “Üniversitelerin Kentlerine Etkileri: Denizli Pamukkale Üniversitesi Örneği”. Süleyman Demirel Üniversitesi İktisadi ve İdari Bilimler Fakültesi Dergisi, C.21, S.1.235-250.

Yılmaz Cevdet, (2011). “Anadolu Kentlerinin Öğrencileşmesi: Başka Bir Kent Deneyimi”. Sosyoloji Dergisi. 25. 1-17. 